Supplement of Atmos. Chem. Phys. Discuss., 15, 23231-23277, 2015

http://www.atmos-chem-phys-discuss.net/15/23231/2015/

doi:10.5194/acpd-15-23231-2015-supplement

(C) Author(s) 2015. CC Attribution 3.0 License.

(c) (i)

\title{
Limited effect of anthropogenic nitrogen oxides on Secondary Organic Aerosol formation
}

\section{Y. Zheng et al.}

Correspondence to: Y. Zheng (yiqi.zheng@yale.edu)

The copyright of individual parts of the supplement might differ from the CC-BY 3.0 licence. 
Table S1. SOA mass yields using default 2-product scheme (Heald et al., 2008 and references therein). The reference temperature is $310 \mathrm{~K}$ for monoterpenes and isoprene, and is $295 \mathrm{~K}$ for benzene, toluene and xylenes. The enthalpy of evaporation is $42 \mathrm{~kJ} \mathrm{~mol}^{-1}$.

\begin{tabular}{|c|c|c|c|c|c|}
\hline Parent HC & Oxidants & $\begin{array}{c}\text { Surrogate } \\
\text { product }\end{array}$ & \multicolumn{2}{|c|}{$\begin{array}{c}\alpha \text { and } C^{*} \\
\left(C^{*} \text { in } \mu \mathrm{g} \mathrm{m}^{-3}\right)\end{array}$} & $\begin{array}{c}\text { Yield at } 10 \\
\mu \mathrm{g} \mathrm{m}^{-3}\end{array}$ \\
\hline \multirow{3}{*}{$\begin{array}{c}\text { Monoterpenes } \\
\mathrm{C}_{10} \mathrm{H}_{16}\end{array}$} & $\mathrm{OH} ; \mathrm{HO}_{2}$ & \multirow{3}{*}{$\begin{array}{c}\text { SOAM } \\
\mathrm{C}_{10} \mathrm{H}_{16} \mathrm{O}_{4}\end{array}$} & $\begin{array}{c}C^{*}=5.435 \\
\alpha=0.067\end{array}$ & $\begin{array}{c}C^{*}=232.6 \\
\alpha=0.354\end{array}$ & 0.06 \\
\hline & $\mathrm{O}_{3} ; \mathrm{HO}_{2}$ & & $\begin{array}{c}C^{*}=5.435 \\
\alpha=0.067\end{array}$ & $\begin{array}{c}C^{*}=232.6 \\
\alpha=0.354\end{array}$ & 0.06 \\
\hline & $\mathrm{NO}_{3}$ & & $\begin{array}{l}C^{*}=61.35 \\
\alpha=1.000\end{array}$ & 0 & 0.14 \\
\hline $\begin{array}{c}\text { Isoprene } \\
\mathrm{C}_{5} \mathrm{H}_{8}\end{array}$ & $\mathrm{OH} ; \mathrm{HO}_{2}$ & $\begin{array}{c}\text { SOAI } \\
\mathrm{C}_{5} \mathrm{H}_{12} \mathrm{O}_{4}\end{array}$ & $\begin{array}{c}C^{*}=0.617 \\
\alpha=0.029\end{array}$ & $\begin{array}{c}C^{*}=116.0 \\
\alpha=0.232\end{array}$ & 0.05 \\
\hline Benzene & $\mathrm{OH} ; \mathrm{HO}_{2}$ & SOAB & $\begin{aligned} C^{*}=0.001 \\
\alpha=0.227\end{aligned}$ & 0 & 0.23 \\
\hline $\mathrm{C}_{6} \mathrm{H}_{6}$ & $\mathrm{OH} ; \mathrm{NO}$ & $\mathrm{C}_{6} \mathrm{H}_{7} \mathrm{O}_{3}$ & $\begin{array}{c}C^{*}=0.302 \\
\alpha=0.044\end{array}$ & $\begin{array}{l}C^{*}=111.1 \\
\alpha=0.545\end{array}$ & 0.09 \\
\hline Toluene & $\mathrm{OH} ; \mathrm{HO}_{2}$ & SOAT & $\begin{array}{l}C^{*}=0.001 \\
\alpha=0.235\end{array}$ & 0 & 0.23 \\
\hline $\mathrm{C}_{7} \mathrm{H}_{8}$ & $\mathrm{OH} ; \mathrm{NO}$ & $\mathrm{C}_{7} \mathrm{H}_{9} \mathrm{O}_{3}$ & $\begin{array}{c}C^{*}=2.326 \\
\alpha=0.038\end{array}$ & $\begin{array}{c}C^{*}=21.28 \\
\alpha=0.074\end{array}$ & 0.05 \\
\hline $\begin{array}{l}\text { Xylenes } \\
\mathrm{C}_{8} \mathrm{H}_{10}\end{array}$ & $\mathrm{OH} ; \mathrm{HO}_{2}$ & $\begin{array}{l}\mathrm{SOAX} \\
\mathrm{C}_{8} \mathrm{H}_{11} \mathrm{O}_{3}\end{array}$ & $\begin{array}{c}C^{*}=0.001 \\
\alpha=0.205\end{array}$ & 0 & 0.20 \\
\hline
\end{tabular}




\begin{tabular}{|l|c|c|c|c|c|}
\hline & OH; NO & & $\mathrm{C}^{*}=1.314$ & $\mathrm{C}^{*}=34.48$ & 0.03 \\
& & & $\alpha=0.021$ & $\alpha=0.061$ & \\
\hline
\end{tabular}


Table S2. SOA mass yields using updated 4-product VBS scheme (Pye et al., 2010 and references therein). The reference temperature is $295 \mathrm{~K}$ and the enthalpy of evaporation is 73 , $62,51,40 \mathrm{~kJ} \mathrm{~mol}^{-1}$ for $\mathrm{C}^{*}$ of $0.1,1,10,100 \mu \mathrm{g} \mathrm{m}^{-3}$, respectively.

\begin{tabular}{|c|c|c|c|c|c|c|c|}
\hline \multirow{2}{*}{ Parent HC } & \multirow{2}{*}{ Oxidants } & \multirow{2}{*}{$\begin{array}{c}\text { Surrogate } \\
\text { product }\end{array}$} & \multicolumn{4}{|c|}{$\alpha$ for $C^{*}\left(C^{*}\right.$ in $\left.\mu \mathrm{g} \mathrm{m}^{-3}\right)$} & \multirow{2}{*}{$\begin{array}{l}\text { Yield at } \\
10 \mu \mathrm{g} \mathrm{m}^{-3}\end{array}$} \\
\hline & & & $C^{*}=0.1$ & $C^{*}=1$ & $C^{*}=10$ & $C^{*}=100$ & \\
\hline \multirow{2}{*}{ Monoter } & $\mathrm{OH} ; \mathrm{HO}_{2}$ & & 0.08 & 0.019 & 0.18 & 0.03 & 0.19 \\
\hline & $\mathrm{OH} ; \mathrm{NO}$ & & 0.04 & 0.0095 & 0.09 & 0.015 & 0.09 \\
\hline \multirow{3}{*}{$\mathrm{C}_{10} \mathrm{H}_{16}$} & $\mathrm{O}_{3} ; \mathrm{HO}_{2}$ & & 0.08 & 0.019 & 0.18 & 0.03 & 0.19 \\
\hline & $\mathrm{O}_{3} ; \mathrm{NO}$ & \multirow{2}{*}{$\mathrm{C}_{10} \mathrm{H}_{16} \mathrm{O}_{4}$} & 0.04 & 0.0095 & 0.09 & 0.015 & 0.09 \\
\hline & $\mathrm{NO}_{3}$ & & 0 & 0 & 0.321 & 1.083 & 0.26 \\
\hline \multirow{2}{*}{$\begin{array}{c}\text { Isoprene } \\
\mathrm{C}_{5} \mathrm{H}_{8}\end{array}$} & $\mathrm{OH} ; \mathrm{HO}_{2}$ & \multirow{2}{*}{$\begin{array}{c}\text { SOAI } \\
\mathrm{C}_{5} \mathrm{H}_{12} \mathrm{O}_{4}\end{array}$} & 0 & 0.031 & 0 & 0.095 & 0.04 \\
\hline & $\mathrm{NO}_{3}$ & & 0 & 0 & 0.217 & 0.092 & 0.12 \\
\hline \multirow{2}{*}{$\begin{array}{c}\text { Benzene } \\
\mathrm{C}_{6} \mathrm{H}_{6}\end{array}$} & $\mathrm{OH} ; \mathrm{HO}_{2}$ & \multirow{2}{*}{$\begin{array}{c}\mathrm{SOAB} \\
\mathrm{C}_{6} \mathrm{H}_{7} \mathrm{O}_{3}\end{array}$} & 0.37 & 0 & 0 & 0 & 0.37 \\
\hline & $\mathrm{OH} ; \mathrm{NO}$ & & 0 & 0.078 & 0 & 0.793 & 0.14 \\
\hline \multirow{2}{*}{$\begin{array}{c}\text { Toluene } \\
\mathrm{C}_{7} \mathrm{H}_{8}\end{array}$} & $\mathrm{OH} ; \mathrm{HO}_{2}$ & \multirow{2}{*}{$\begin{array}{l}\text { SOAT } \\
\mathrm{C}_{7} \mathrm{H}_{9} \mathrm{O}_{3}\end{array}$} & 0.36 & 0 & 0 & 0 & 0.36 \\
\hline & $\mathrm{OH} ; \mathrm{NO}$ & & 0 & 0.032 & 0.094 & 0.080 & 0.08 \\
\hline \multirow{2}{*}{$\begin{array}{c}\text { Xylene } \\
\mathrm{C}_{8} \mathrm{H}_{10}\end{array}$} & $\mathrm{OH} ; \mathrm{HO}_{2}$ & \multirow{2}{*}{$\begin{array}{l}\text { SOAX } \\
\mathrm{C}_{8} \mathrm{H}_{11} \mathrm{O}_{3}\end{array}$} & 0.30 & 0 & 0 & 0 & 0.30 \\
\hline & $\mathrm{OH} ; \mathrm{NO}$ & & 0 & 0.025 & 0.036 & 0.090 & 0.05 \\
\hline
\end{tabular}




\section{Change in NO emissions}

Rel. change in NO emissions
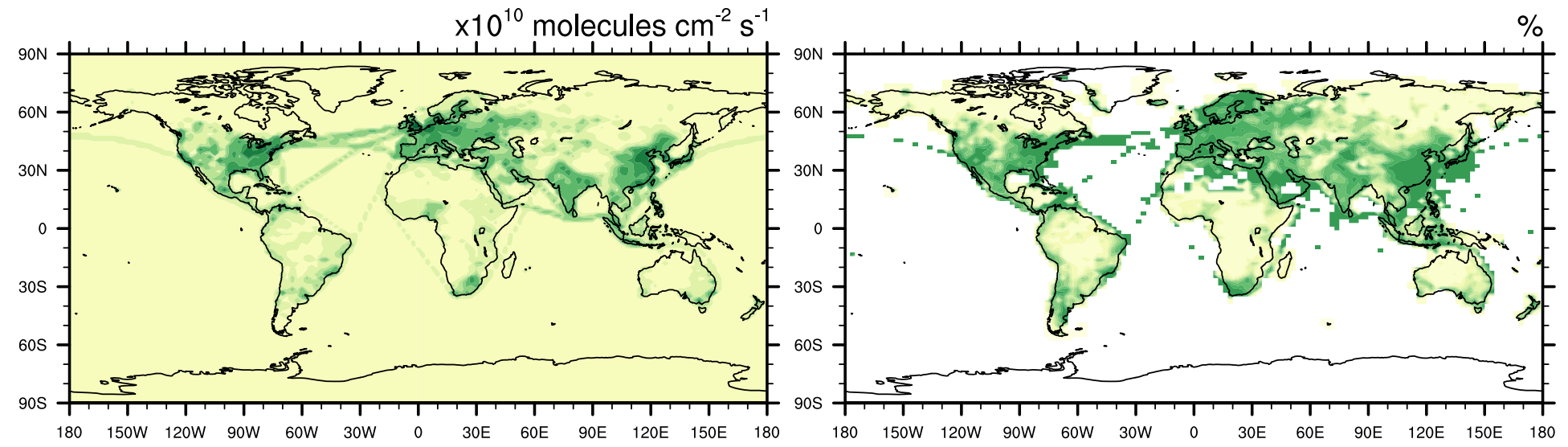

\section{Change in $\mathrm{NO}_{\mathrm{x}}$ concentration}

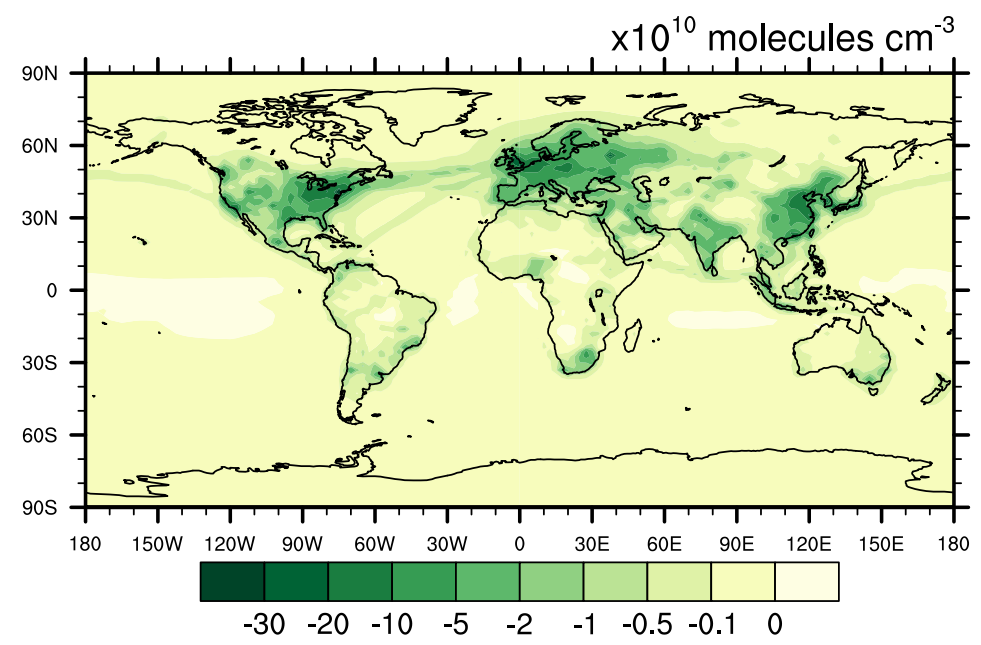

Rel. change in $\mathrm{NO}_{x}$ concentration

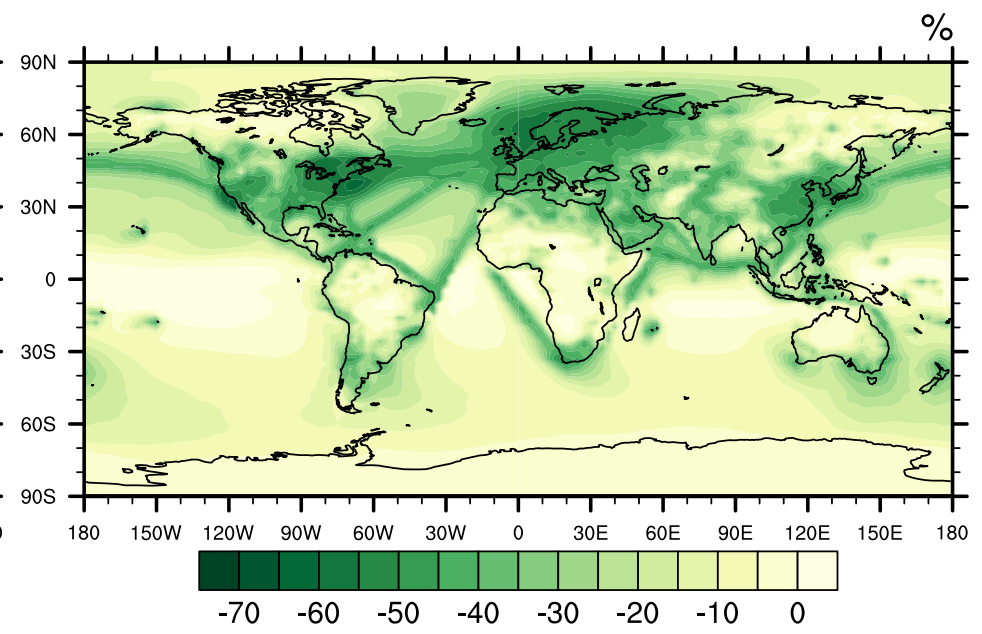

Figure S1. Absolute (left column) and relative (right column) changes of annual mean NO emissions (units: $\times 10^{10}$ molecules $\mathrm{cm}^{-2} \mathrm{~s}^{-1}$ ) and simulated surface $\mathrm{NO}_{\mathrm{x}}$ concentration (units: $\times 10^{10}$ molecules $\mathrm{cm}^{-3}$ ) in the sensitivity run compared to the control run using VBS_agHigh scheme. Data are averaged from 2005 to 2009. 
Change in $\mathrm{OH}$ concentration



Change in $\mathrm{O}_{3}$ concentration

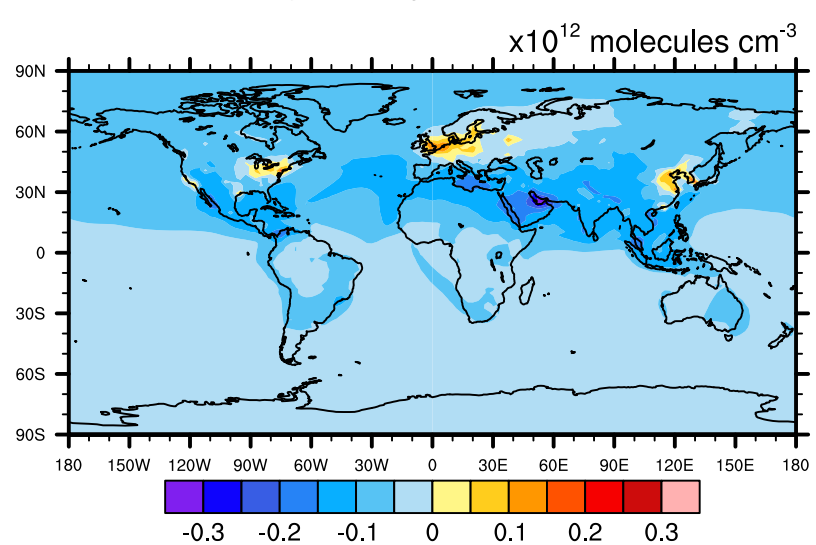

Change in $\mathrm{NO}_{3}$ concentration

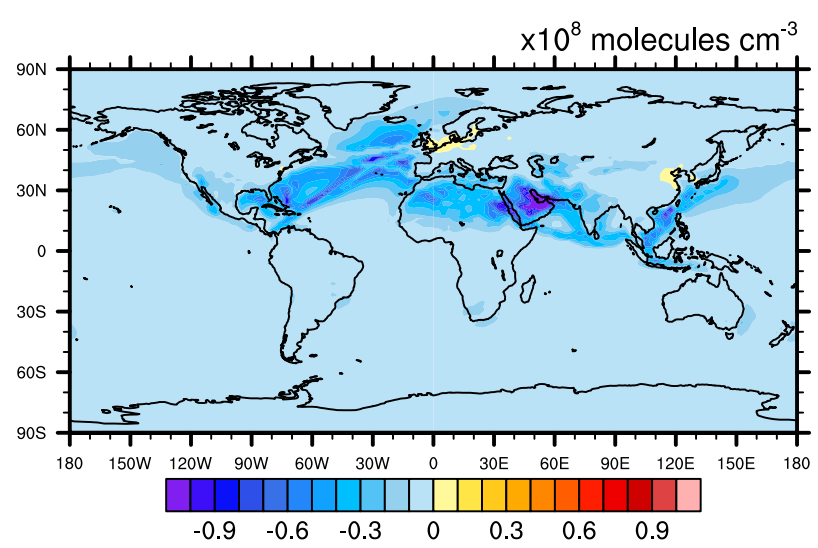

Rel. change in $\mathrm{OH}$ concentration

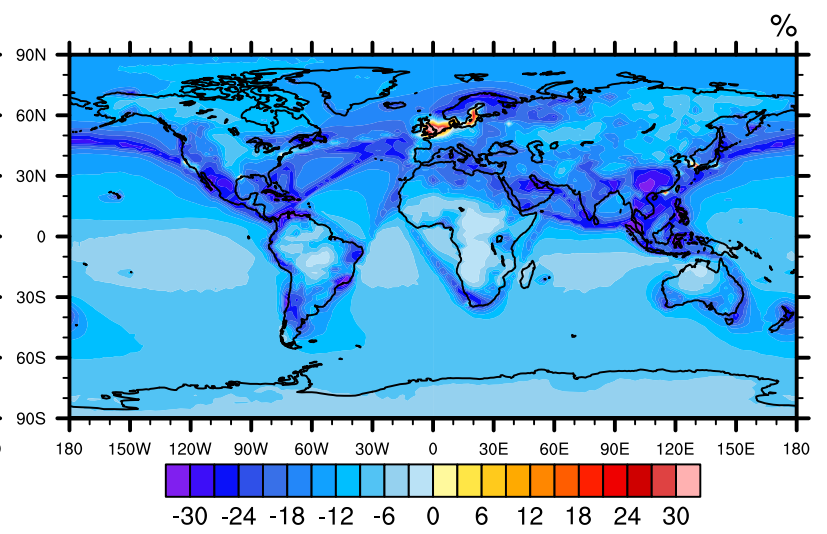

Rel. change in $\mathrm{O}_{3}$ concentration

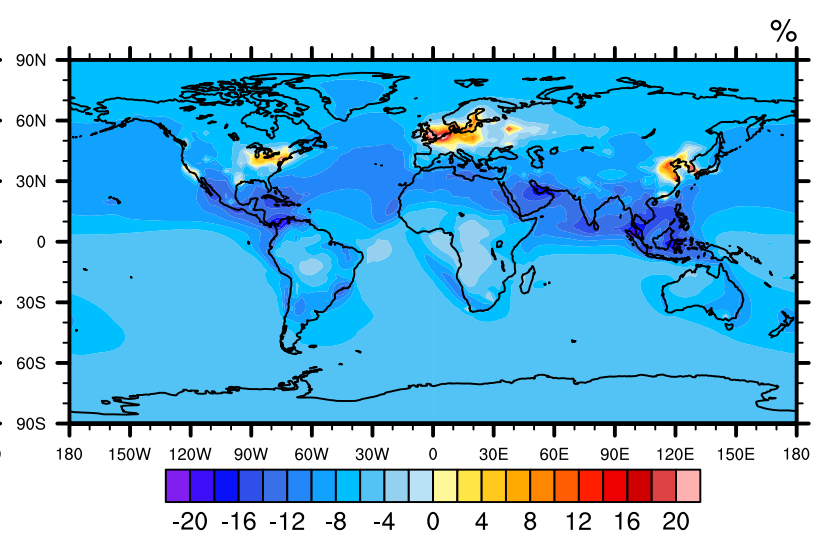

Rel. change in $\mathrm{NO}_{3}$ concentration

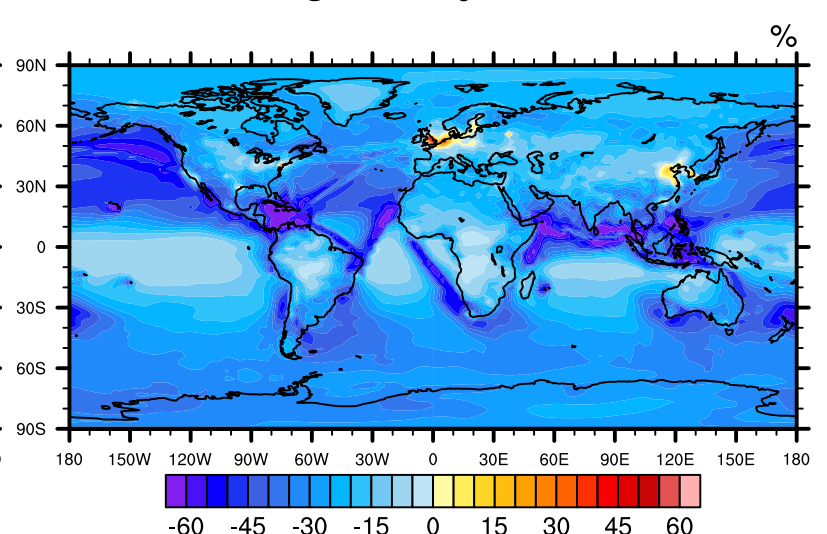

Figure S2. Absolute (left column) and relative (right column) changes of simulated annual mean surface $\mathrm{OH}$ $\left(\times 10^{6}\right.$ molecules $\left.\mathrm{cm}^{-3}\right), \mathrm{O}_{3}\left(\times 10^{12}\right.$ molecules $\left.\mathrm{cm}^{-3}\right)$ and $\mathrm{NO}_{3}$ concentrations $\left(\times 10^{8}\right.$ molecules $\left.\mathrm{cm}^{-3}\right)$ in the sensitivity run compared to the control run using VBS_agHigh scheme. Data are averaged from 2005 to 2009. Note that the range of color bars are different in each subplot. 

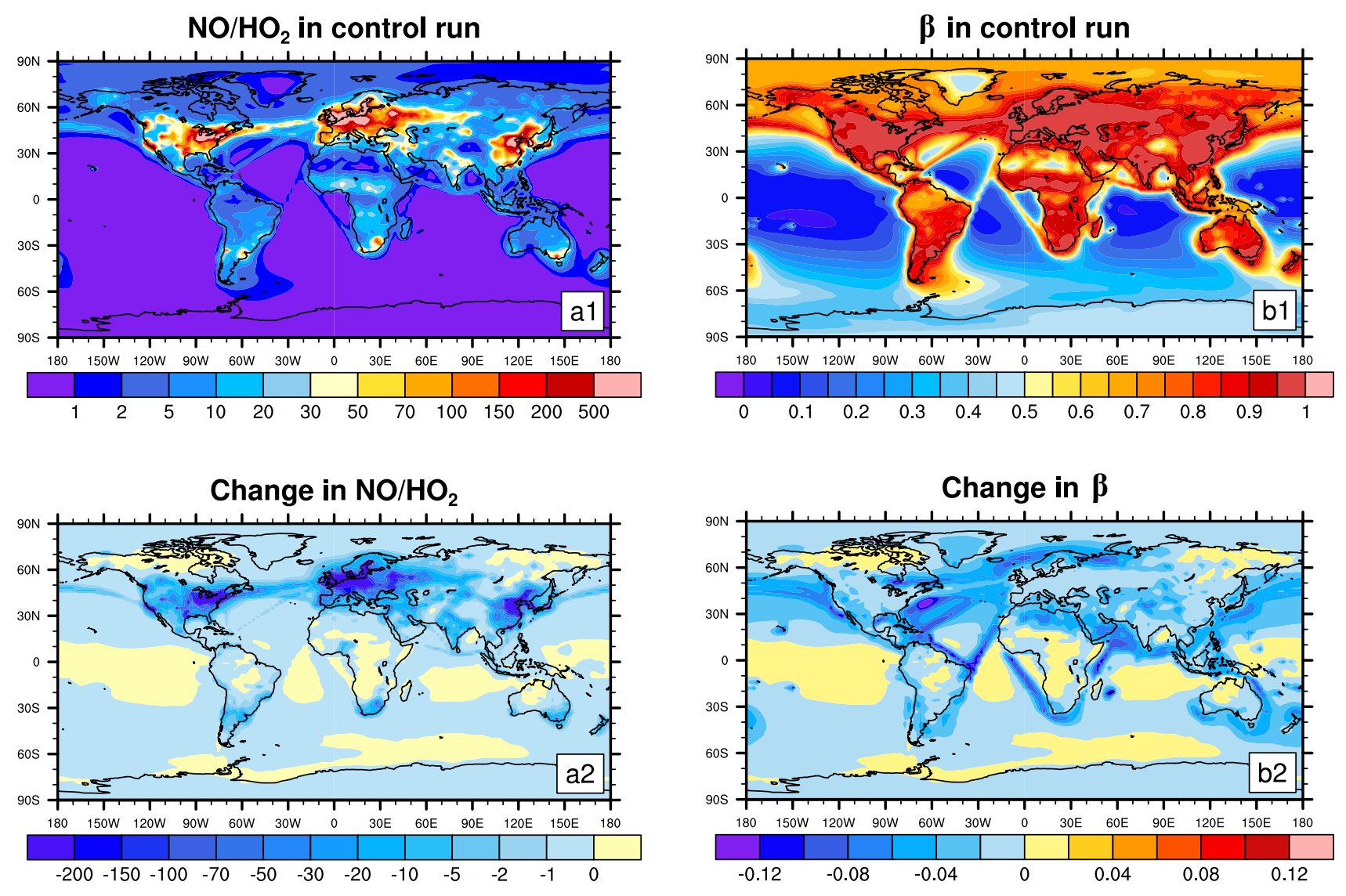

Rel. change in $\mathrm{NO} / \mathrm{HO}_{2}$
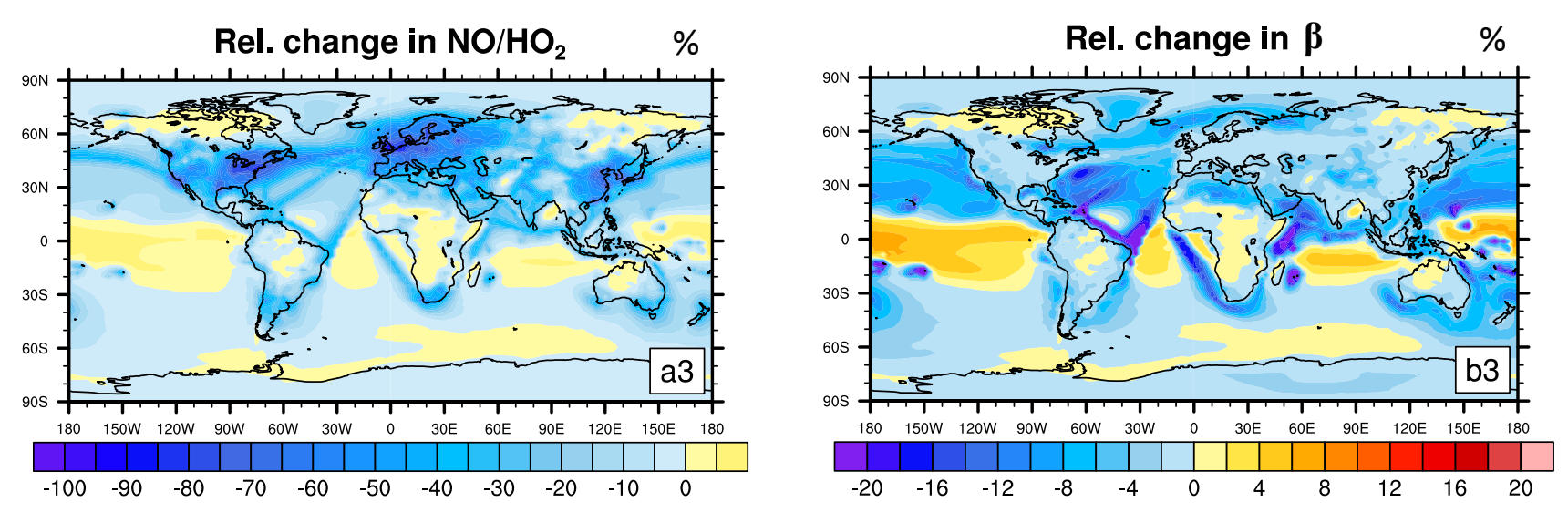

Figure S3. Left column: (a1) is the annual mean surface $\mathrm{NO}-\mathrm{to}-\mathrm{HO}_{2}$ ratio $\left(\mathrm{NO} / \mathrm{HO}_{2}\right)$ in the control run; (a2) and (a3) are the absolute and relative change of $\mathrm{NO} / \mathrm{HO}_{2}$ in the sensitivity run compared to the control run. Right column is similar to the left column but for annual mean surface branching ratio ( $\beta$ ). Simulations use VBS_agHigh scheme. Data are averaged from 2005 to 2009. Note that the range of color bars are different in each subplot. 

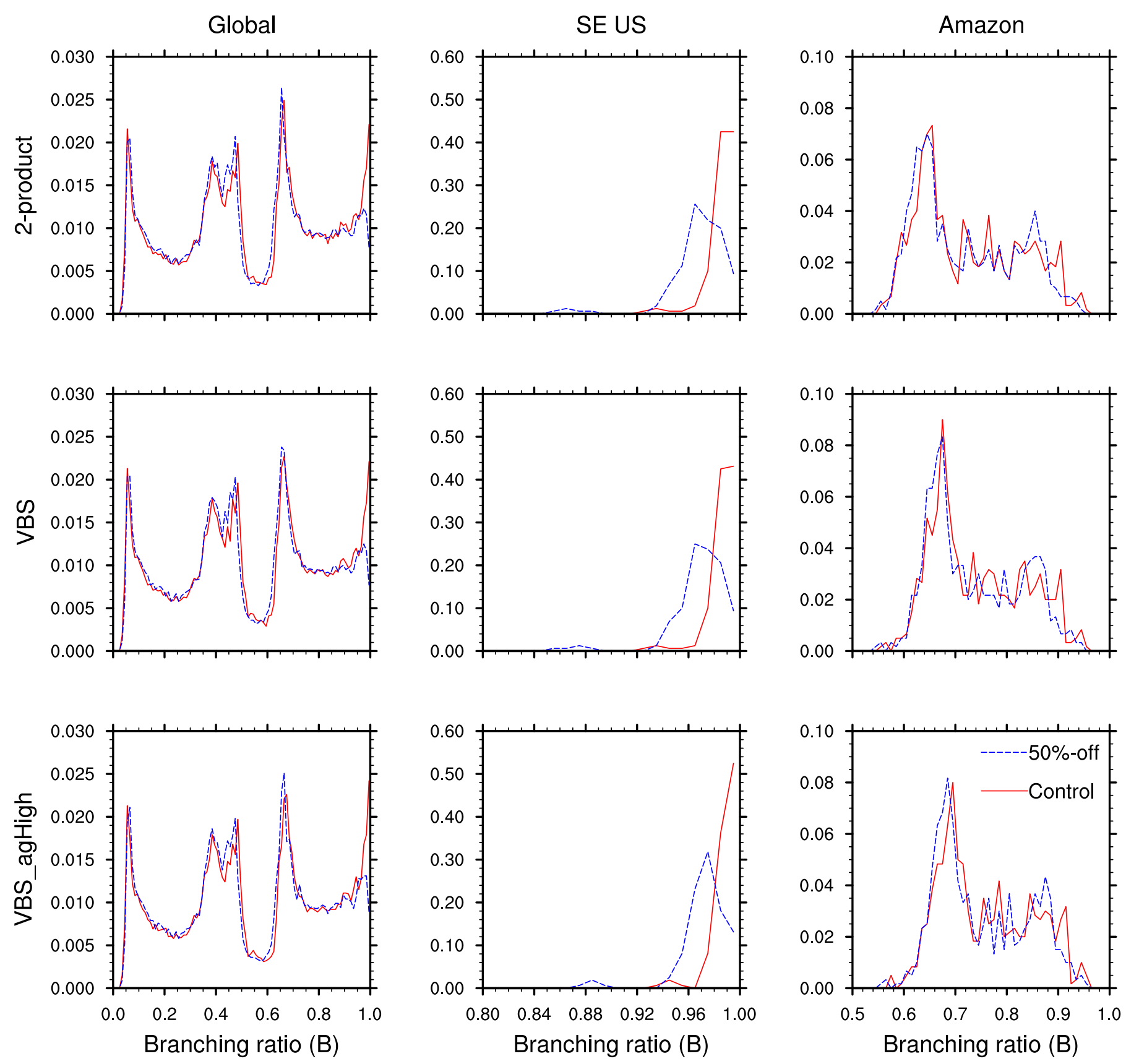

Figure S4. Probability density function of annual mean surface branching ratio ( $\beta$ ) at global scale, in the southeast US and in the Amazon. 